75 years of Agricultural University - Plovdiv

JUBILEE SCIENTIFIC INTERNATIONAL

CONFERENCE Plovdiv 26-28 November 2020
PERSPECTIVES ON AGRICULTURAL SCIENCE AND INNOVATIONS FOR SUSTAINABLE FOOD SYSTEMS

\title{
DOI: 10.22620/agrisci.2021.29.004 \\ MANAGEMENT OF THE PESTS IN THE CONVENTIONAL AND BIOLOGICAL SYSTEMS FOR PEA GROWING
}

\author{
Vinelina Yankova*, Dima Markova, Slavka Kalapchieva \\ Maritsa Vegetable Crops Research Institute - Plovdiv \\ *E-mail: vinelina@abv.bg
}

\begin{abstract}
Pea (Pisum sativum L.) is a valuable grain legume crop, the seeds of which are used for human food and fodder. The seeds are consumed in a mature or green state. The priorities of the peas as a crop are the following: it is a legume, which enriches the soil with nitrogen; peas are the best possible precursor - clears the areas early; non-particular to soil and growing conditions; high protein content crop. However, the growing process of this crop could be worse by various pests that lead to product quality decay or they could even destroy the pea production. Economically important pests in field cultivation of peas are: pea aphid (Acyrthosiphon pisum Harris), pea weevil (Bruchus pisi L.) and pea moths (Laspeyresia nigricana Step. and Laspeyresia dorsana L.). Field experiments on pea variety Paldin were conducted at the Maritsa Vegetable Crops Research Institute, Plovdiv to determine the effectiveness of different plant protection products against a natural background of pest infestation. The biological activity of the insecticides Deca EC $50 \mathrm{ml} / \mathrm{da}$ (a. i. deltamethrin), Oasis $5 \mathrm{EC} 25 \mathrm{ml} / \mathrm{da}$ (a. i. esfenvalerate), Piretro Natura EC $75 \mathrm{ml} /$ da (a. i. pyrethrins), Neem Azal T/S 0.3\% (a. i. azadirachtin), Naturalis $100 \mathrm{ml} / \mathrm{da}$ (a. i. Beauveria bassiana), Dipel 2 X $100 \mathrm{~g} / \mathrm{da}$ (a. i. Bacillus thuringiensis var. kurstaki strain ABTS) and Rapax $100 \mathrm{ml} / \mathrm{da}$ (a. i. Bacillus thuringiensis subsp. kurstaki, strain EG 2348) against the main pests of peas in conventional and biological production systems was established.
\end{abstract}

Key words: pea, pests, insecticides, conventional and biological production

\section{INTRODUCTION}

Pea (Pisum sativum L.) is an important grain legume crop. Many abiotic and biotic factors limit the productivity of pea. Among the biotic constraints, insect pests are main factors limiting the pea yield. Over 15 insect pests are known to feed on pea, however only a few of these insect herbivores are known to cause a considerable amount of losses in pea production. They attack all parts of the plant at different stages, from sowing to harvest (French, 2004; Sharma et al., 2010; Yadav and Patel, 2015).

The pea aphid, Acyrthosiphon pisum Harris (Homoptera: Aphididae) is a serious pest in pea (Pisum sativum L.) crops causing large yield losses. A. pisum generally feeds on the lower surface of leaflets, and on buds and pods of pea plants, from which it ingests phloem nutrients (Carrillo et al., 2013). Severe damage can occur to peas due to direct feeding and virus spread. Direct feeding on pea results in sap being removed from terminal leaves and the stem. Heavy infestations on pea can cause stunting, deformation, wilting and even death. Aphids can also feed on pods, causing them to curl, shrink and only partially fill. Direct feeding therefore leads to yield loss and reductions in crop quality (Megersa, 2016). Plants infested up to time of flowering recovered from the damage and their yield is normal. With a longer attack from plant growth to flower opening or longer reduces dry matter production, reduces the number of pods per plant and the number of seeds per pod, increases the percentage of empty 
75 years of Agricultural University - Plovdiv JUBILEE SCIENTIFIC INTERNATIONAL CONFERENCE Plovdiv 26-28 November 2020
PERSPECTIVES ON AGRICULTURAL SCIENCE AND INNOVATIONS FOR SUSTAINABLE FOOD SYSTEMS pods, reduces the weight of 1000 seeds and yield, reduces the weight of nitrogen-fixing root nodules, but does not affect the protein content of seeds (Maiteki and Lamb, 1985).

The pea weevil (Bruchus pisi L.) (Coleoptera: Bruchidae), is a primary limiting factor for worldwide production of pea. Female lay the eggs on the surface of immature pea pods and hatch to produce larvae (neonate to firstinstar) that burrow through the pod wall from the underside of eggs. After boring through the pod wall, first-instar larvae bore into a seed to reach cotyledon tissue, their ultimate food source. Larval development occurs within a single seed in a pod (Clement et al., 2009).

The pea moth, Laspeyresia nigricana Steph., is one of the principal pests of garden and field peas. Its larvae feed within the pods causing considerable damage to the developing seeds and giving to their contents a very unsightly appearance (Wright and Geering, 2009).

Although, the insect pests are controlled by diversified measures but chemical control of insect pests is yet considered as more effective than rest of the methods. However, chemical insecticides are applied only if the insect population crosses the economic threshold level and control measures are taken when population exceeds economic threshold level (Sahito et al., 2013).

Natural pesticides are pesticides made by organisms usually for their own defense, or are derived from a natural source such as plant, animal, bacteria, fungi and certain mineral, use to control pest naturally. The common natural pesticides uses are neem (Azadiracta indica), microbial pesticide Bacillus thuringiensis and pyrethrins. Natural pesticides usually target specific sites in the insect such as nervous system, resulting in knock-down, lack of coordination, paralysis and death (Oguh et al., 2019). The primary active ingredient of most neem-based pesticides is azadiractin, a liminoid compound, which has multiple biological activities on more than 400 insect species from several orders. Azadirachtin-based compounds have insecticidal, feeding deterrent, repellent, antioviposition, and physiological properties (Shannag et al., 2014).

Pyrethrum, also known as pyrethrins, is extracted from the seed of Chrysanthemum cinerariaefolium. Pyrethrum is effective against a wide range of pests such as whitefly, mealybugs and thrips, but will not control mites. Pyrethrins have a rapid "knockdown" effect preceding insect death and insects usually die in a few minutes or hours following exposure to a fatal dose (Fernández-Grandon et al., 2020).

Bacillus thuringiensis is an aerobic Gram- positive endospore-forming bacterium which is a part of the family Bacillaceae and it is widely used in agriculture as a biological pesticide. Commercial formulations of $B$. thuringiensis have been used for the last few decades in the control of lepidopteran insects and, in more recent times, beetles and flies. Many of these products are based on sporecrystal preparations derived from a small number of wild-type strains (HernándezFernández, 2016). After ingestion by a herbivorous insect, the crystal dissolves in the alkaline environment of the insect midgut, releasing one or more insecticidal crystalline proteins, also known as a delta-endotoxin. They can be activated by midgut proteases. Once activated, the crystalline proteins interact with larval midgut epithelial cells and destroy membrane integrity, ultimately leading to insect death (Xiao and $\mathrm{Wu}, 2019$ ).

Pest management through biological control is confident using different predators, parasites and pathogens. Entomopathogenic fungi are considered unique compared to other micropathogens. Entomopathogenic fungi can be used for pest control and do not affect on other non-target organisms (Abdou et al., 2017). Beauveria bassiana (Balsamo) Vuillemin is a generalist entomopathogen and has been found infecting many arthropod species, including 
75 years of Agricultural University - Plovdiv JUBILEE SCIENTIFIC INTERNATIONAL CONFERENCE Plovdiv 26-28 November 2020
PERSPECTIVES ON AGRICULTURAL SCIENCE AND INNOVATIONS FOR SUSTAINABLE FOOD SYSTEMS members of the Coleoptera, Hemiptera, and Diptera (Baverstock et al., 2006). One of the advantages of entomopathogenic fungi is that the host insect need not ingest them. Entomopathogenic fungi, such as Beauveria bassiana, infect the host insect by penetrating the insect cuticle. Germ tubes grow through the layers of the cuticle using the enzymatic action and finally enter the haemocoel (Anderson et al., 1995; Fan et al., 2007).

The aim of the study was to determine the effectiveness of various plant protection products against major pests in pea grown in open field conditions.

\section{MATERIALS AND METHODS}

The studies were conducted in 20192020 at "Maritsa" VCRI - Plovdiv in the field under a natural background of pest infestation, in condition of conventional and biological production of pea variety Paldin.

Aphids (Homoptera: Aphididae)

In aphid-infested pea plants are sprayed with the appropriate concentration/dose of insecticide. The number of live individuals before spraying and at intervals after 1, 3, 5, 7, 10 and 14 days on pre-marked pea plants was counted. Test pest: pea aphid (Acyrthosiphon pisum Harris). Test products for plant protection: conventional production - Deca EC $50 \mathrm{ml} / \mathrm{da}$ (a. i. deltamethrin) and biological production - Piretro Natura EC in a dose of 75 $\mathrm{ml} / \mathrm{da}$ (a. i. pyrethrins), Naturalis $100 \mathrm{ml} / \mathrm{da}$ (a. i. Beauveria bassiana). Total area of the experimental plot $200 \mathrm{~m}^{2}$ conventional and 200 $\mathrm{m}^{2}$ biological pea production. The effectiveness (E\%) was calculated by the formula (Henderson and Tilton, 1955):

$$
E \%=\left(1-\frac{T a x C b}{T b x C a}\right) \cdot 100
$$

$T a$ - number of live aphids in the variant after treatment; $T b$ - number of live aphids in the variant before treatment; $C a$ - number of live aphids in the control after treatment; $C b$ - number of live aphids in the control before treatment.

Pea weevil (Bruchus pisi L.)

Field experiments were performed on pea variety Paldin. The insecticides were sprayed twice at intervals of 7 days. Test products for plant protection: conventional production - Oasis 5 EC $25 \mathrm{ml} / \mathrm{da}$ (a. i. esfenvalerate) and biological production Piretro Natura EC in a dose of $75 \mathrm{ml} / \mathrm{da}$ (a. i. pyrethrins), Neem Azal T/S $0.3 \%$ (a. i. azadirachtin). The first treatment was carried out during flowering and the formation of the first pods at the establishment of 10 numbers $/ 100$ plants. Total area of the experimental plot $200 \mathrm{~m}^{2}$ conventional and 200 $\mathrm{m}^{2}$ biological pea production. After harvesting the peas from the field, average samples of 500 seeds were taken. They are placed in glass jars insulated with cheesecloth at room temperature for 50 days. The percentage of damaged seeds was then recorded and the effectiveness (\%) was calculated (Abbott, 1925).

$$
E=\left(\frac{I k-I v}{I k}\right) \cdot 100(\%), \text { where }
$$

$E$ - effectiveness, $\%$; $I k$ - percentage of infested seeds in the control (\%); Iv - percentage of infested seeds in the variant (\%).

Pea moths (Laspeyresia nigricana Step. and L. dorsana L.)

Field experiments were performed on pea variety Paldin, under natural infestation by pea moths. It was sprayed twice with insecticides at intervals of 7 days. Test plant protection products: conventional production Deca EC $50 \mathrm{ml} / \mathrm{da}$ (a. i. deltamethrin) and biological production - Rapax $100 \mathrm{ml} / \mathrm{da}$ (a. i. Bacillus thuringiensis, subsp. kurstaki, strain EG 2348), Dipel 2 X 100 g/da (a. i. Bacillus thuringiensis var. kurstaki strain ABTS), Neem Azal T/S $0.3 \%$ (a. i. azadirachtin). The first treatment was carried out during flowering and the formation of the first pods. Total area of the experimental plot $200 \mathrm{~m}^{2}$ conventional and 200 $\mathrm{m}^{2}$ biological pea production. After harvesting 
75 years of Agricultural University - Plovdiv JUBILEE SCIENTIFIC INTERNATIONAL CONFERENCE Plovdiv 26-28 November 2020
PERSPECTIVES ON AGRICULTURAL SCIENCE AND INNOVATIONS FOR SUSTAINABLE FOOD SYSTEMS the peas from the field, average samples of 500 seeds per variant were taken. The percentage of damaged seeds was reported and the effectiveness (\%) was calculated (Abbott, 1925).

The experiments with biological plant protection products were conducted in a certified biological field.

Data were processed using Duncan's multiple range test at $\mathrm{P}<0.05$ levels (Duncan, 1955).

\section{RESULTS AND DISCUSSION}

The use of chemical plant protection products is one of the widely used and effective methods for pest control. Unfortunately, there are risks of environmental pollution and the appearance of resistance in populations. Therefore, attempts are being made to determine the effectiveness not only of chemical insecticides but also of biological products as an alternative possibility for pest control.

In conventional pea production, the insecticide Deca EC showed the highest effectiveness of $83.11 \%$ 5th day after treatment against pea aphid (Picture 1). This insecticide shows a relatively good initial effect. An effectiveness of $63.68 \%$ was reported on the first day after treatment. Bioproduct Piretro Natura EC $75 \mathrm{ml} / \mathrm{da}$ has a relatively good biological activity $(\mathrm{E}=78.46 \%$ at 5 th day after treatment) close to that of Deca EC $50 \mathrm{ml} / \mathrm{da}$, which is probably due to the good contact action of pyrethrins similar to pyrethroids. The biological product Naturalis $100 \mathrm{ml} / \mathrm{da}$ demonstrates a slower effect, typical for the microbial products. It has a longer duration of action, as at the end of the period effectiveness of $57.94 \%$ for this treatment was reported, while the biological activity for the other products is below $55.00 \%$. A maximum value of effectiveness $75.28 \%$ was reported in 7 days after treatment. This product can also be successfully included into biological pea production systems (Table 1).

Table 1. Effectiveness of plant protection products against pea aphid (Acyrthosiphon pisum Harris)

\begin{tabular}{|c|c|c|}
\hline Variants & $\begin{array}{l}\text { Days after } \\
\text { treatment }\end{array}$ & $\mathrm{E},(\%)$ \\
\hline Deca EC $50 \mathrm{ml} / \mathrm{da}$ & \multirow{3}{*}{1} & $63.68 \mathrm{bc}$ \\
\hline Piretro Natura EC $75 \mathrm{ml} / \mathrm{da}$ & & $51.67 \mathrm{bc}$ \\
\hline Naturalis $100 \mathrm{ml} / \mathrm{da}$ & & $47.76 \mathrm{~b}$ \\
\hline Deca EC $50 \mathrm{ml} / \mathrm{da}$ & \multirow{3}{*}{3} & $80.07 \mathrm{ab}$ \\
\hline Piretro Natura EC $75 \mathrm{ml} / \mathrm{da}$ & & $71.58 \mathrm{ab}$ \\
\hline Naturalis $100 \mathrm{ml} / \mathrm{da}$ & & $63.16 \mathrm{ab}$ \\
\hline Deca EC $50 \mathrm{ml} / \mathrm{da}$ & \multirow{3}{*}{5} & 83.11 a \\
\hline Piretro Natura EC $75 \mathrm{ml} / \mathrm{da}$ & & 78.46 a \\
\hline Naturalis $100 \mathrm{ml} / \mathrm{da}$ & & $74.36 \mathrm{a}$ \\
\hline Deca EC $50 \mathrm{ml} / \mathrm{da}$ & \multirow{3}{*}{7} & $73.75 \mathrm{ac}$ \\
\hline Piretro Natura EC $75 \mathrm{ml} / \mathrm{da}$ & & $67.64 \mathrm{ac}$ \\
\hline Naturalis $100 \mathrm{ml} / \mathrm{da}$ & & $75.28 \mathrm{a}$ \\
\hline Deca EC $50 \mathrm{ml} / \mathrm{da}$ & \multirow{3}{*}{10} & $61.16 \mathrm{bc}$ \\
\hline Piretro Natura EC $75 \mathrm{ml} / \mathrm{da}$ & & $54.04 \mathrm{bc}$ \\
\hline Naturalis $100 \mathrm{ml} / \mathrm{da}$ & & $62.77 \mathrm{ab}$ \\
\hline Deca EC $50 \mathrm{ml} / \mathrm{da}$ & \multirow{3}{*}{14} & $55.00 \mathrm{c}$ \\
\hline Piretro Natura EC $75 \mathrm{ml} / \mathrm{da}$ & & $43.93 \mathrm{c}$ \\
\hline Naturalis $100 \mathrm{ml} / \mathrm{da}$ & & $57.94 \mathrm{ab}$ \\
\hline
\end{tabular}

$\mathrm{a}, \mathrm{b}, \mathrm{c}$. .-Duncan's multiple range test $(\mathrm{p}<0.05)$.

The product Oasis 5 EC $25 \mathrm{ml} / \mathrm{da}$ demonstrated very good effectiveness $-92.06 \%$ in the field experiments, conducted for determining the effectiveness of the tested products against pea weevil (Picture 3 and 4). Oasis $5 \mathrm{EC}$ is an insecticide from the group of pyrethroids, with stomachic and contact action, with fast initial effect and good post-effect. The treatments carried out with this product can ensure well-preserved production of seeds in the field. The phytopesticide Neem Azal T/S 0.3\% shows relatively good biological activity $(\mathrm{E}=$ $66.96 \%$ ) against this pest. The product might be applied into the biological production systems as an alternative for control of B. pisi. Neem Azal T/S is a systemic insecticide, characterized by a strong inhibitory effect in the juvenile stages of insects. This insecticide disrupts the normal cycle of conversion in insects by blocking the release of the hormone ecdysone in larvae, thus stopping the moulting and passing to another age. It reduces vital activity in adults 
75 years of Agricultural University - Plovdiv JUBILEE SCIENTIFIC INTERNATIONAL CONFERENCE Plovdiv 26-28 November 2020
PERSPECTIVES ON AGRICULTURAL SCIENCE AND INNOVATIONS FOR SUSTAINABLE FOOD SYSTEMS and impairs the maturation of eggs in females after entering their body. Therefore, they do not lay eggs. The biological product Piretro Natura EC $75 \mathrm{ml} /$ da has an inadequate effectiveness of $60.71 \%$ against this pest (Table 2). This is probably due to the short contact action.

Table 2. Effectiveness of plant protection products against pea weevil (Bruchus pisi L.) in cultivation of pea variety Paldin in two production systems

\begin{tabular}{|l|c|c|}
\hline \multicolumn{1}{|c|}{ Variant } & $\begin{array}{c}\text { Infested } \\
\text { seeds, \% }\end{array}$ & E, \% \\
\hline Conventional production \\
\hline Oasis 5 EC 25 ml/da & 3.00 & 92.06 \\
\hline Control & 37.80 & - \\
\hline Biological production & \multicolumn{1}{|l}{} \\
\hline Piretro Natura EC 75 ml/da & 14.80 & 66.96 \\
\hline Neem Azal T/C 0.3\% & 17.60 & 60.71 \\
\hline Control & 44.80 & - \\
\hline
\end{tabular}

The control of pea moths (Picture 2) is difficult due to the screened lifestyle of the caterpillars. Treatments should be carried out at the appropriate time before their nibbled at the pods and seeds. From the tested products, the contact insecticide Deca EC $50 \mathrm{ml} / \mathrm{da}$ shows very good effectiveness $(E=81.48 \%)$ and can be used in conventional plant protection systems

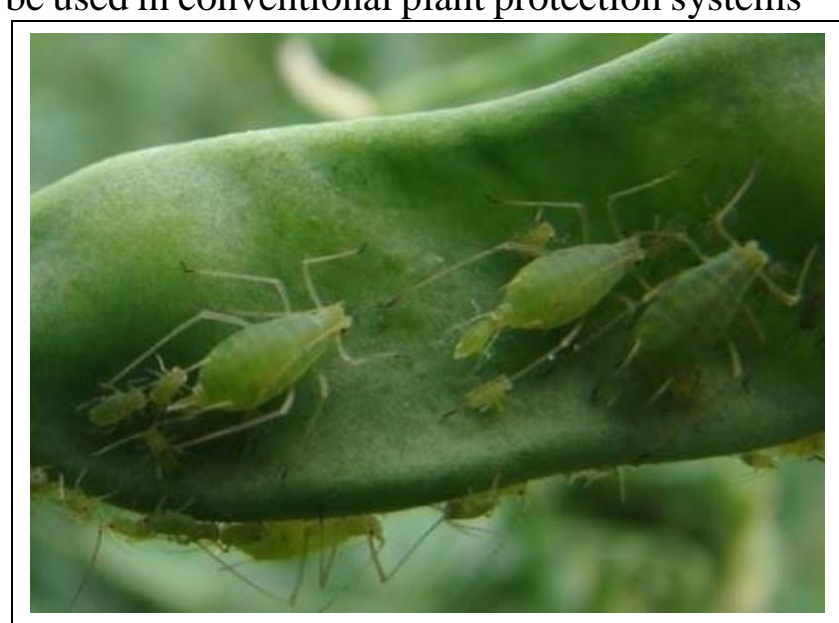

Picture 1. Pea aphid (Acyrthosiphon pisum Harris) to control these pests. From the biological products Dipel 2 X $100 \mathrm{~g} / \mathrm{da}$ shows the best effectiveness $-72.73 \%$. This insecticide can be used to control Laspeyresia spp. in biological production systems. Our results confirm those of Wrzodak and Rybczyński (2010) for the good biological activity of the product Dipel $2 \mathrm{X}$ against moths. The product Rapax $100 \mathrm{ml} / \mathrm{da}$ showed a satisfactory effectiveness of $68.18 \%$, and the phytopisticide Neem Azal T/S 0.3\% had inadequate biological activity $(\mathrm{E}=63.64 \%)$ (Table 3).

Table 3. Effectiveness of plant protection products against pea moths (Laspeyresia nigricana Step. and L. dorsana L.) in cultivation of pea variety Paldin in two production systems

\begin{tabular}{|l|c|c|}
\hline \multicolumn{1}{|c|}{ Variant } & Infested seeds, \% & E, \% \\
\hline Conventional production & \multicolumn{1}{|l|}{} \\
\hline Deca EC $50 \mathrm{ml} / \mathrm{da}$ & 1.00 & 81.48 \\
\hline Control & 5.40 & - \\
\hline Biological production & \multicolumn{2}{|l|}{} \\
\hline Rapax $100 \mathrm{ml} / \mathrm{da}$ & 1.40 & 68.18 \\
\hline Dipel 2 X 100 g/da & 1.20 & 72.73 \\
\hline Neem Azal T/C 0.3\% & 1.60 & 63.64 \\
\hline Control & 4.40 & - \\
\hline
\end{tabular}

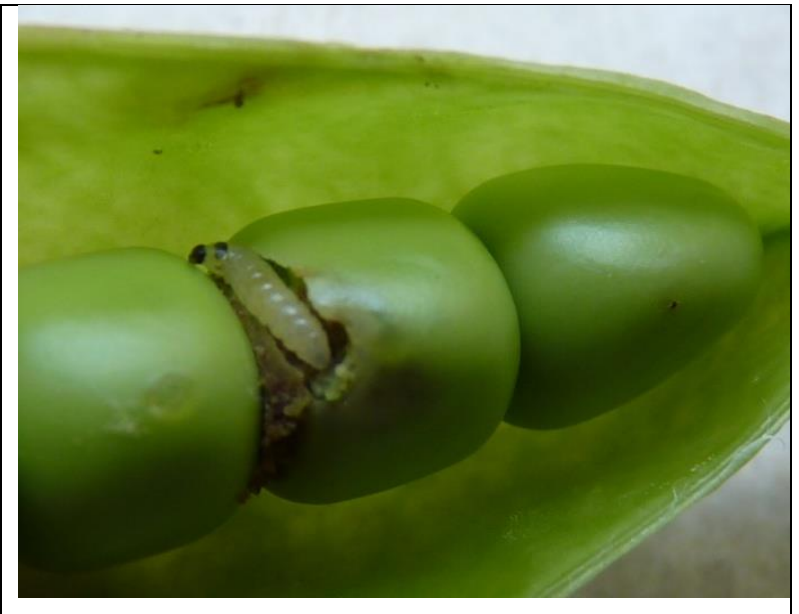

Picture 2. Pea moths (Laspeyresia spp.) 
75 years of Agricultural University - Plovdiv JUBILEE SCIENTIFIC INTERNATIONAL CONFERENCE Plovdiv 26-28 November 2020
PERSPECTIVES ON AGRICULTURAL SCIENCE AND INNOVATIONS FOR SUSTAINABLE FOOD SYSTEMS

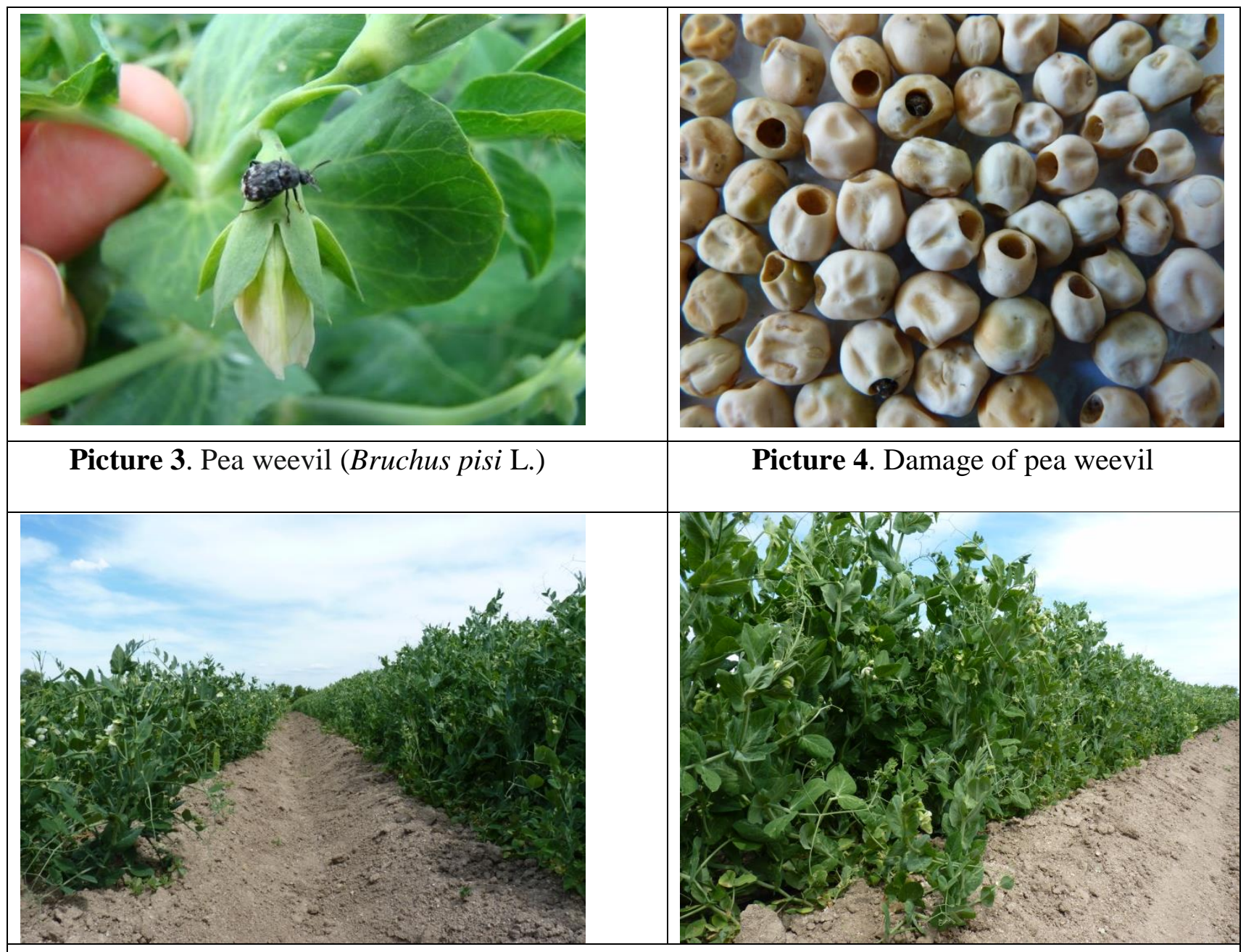

Picture 5. Growing of pea crop

\section{CONCLUSIONS}

The product Deca EC $50 \mathrm{ml} / \mathrm{da}$ and the bioproducts Piretro Natura EC $75 \mathrm{ml} / \mathrm{da}$ and Naturalis $100 \mathrm{ml} / \mathrm{da}$ have good aficidal activity and can be included for effective control on pea aphid (Acyrthosiphon pisum Harris) in the respective conventional and biological system for pea growing.

The product Oasis $5 \mathrm{EC} 25 \mathrm{ml} / \mathrm{da}$ and the phytopesticide Neem Azal T/S $0.3 \%$ have good biological activity against pea weevil (Bruchus pisi L.) and can be used in conventional and biological systems for pea growing, respectively.

The insecticide Deca EC $50 \mathrm{ml} / \mathrm{da}$ and the bioproduct Dipel 2 X $100 \mathrm{~g} / \mathrm{da}$ are effective against pea moths (Laspeyresia nigricana Step. and L. dorsana L.) and can be included in conventional and biological systems for pea growing.

\section{ACKNOWLEDGEMENTS}

This work was supported by the Bulgarian Ministry of Education and Science under the National Research Programme "Healthy Foods for a Strong Bio-Economy and Quality of Life" approved by DCM \# 577 /17.08.2018" 
75 years of Agricultural University - Plovdiv

JUBILEE SCIENTIFIC INTERNATIONAL

CONFERENCE Plovdiv 26-28 November 2020
PERSPECTIVES ON AGRICULTURAL SCIENCE AND INNOVATIONS FOR SUSTAINABLE FOOD SYSTEMS

\section{REFERENCES}

Abbott, W. S., 1925. A method of computing the effectiveness of an insecticide. J. Econ. Entomol., 18 : 265-267.

Abdou, W. L., E. A. Abdel-Hakim, H. M. Metwally, 2017. Influence of Entomopathogenic FungusBeauveria bassianaon the Mortality, Reproduction and Enzyme Activity of the Aphid Adults Aphis craccivora (Koch). Middle East J. Appl. Sci., 7(3): 567-573.

Anderson, S. O., P. Hojrup, P. Roepstorff, 1995. Insect cuticular proteins. Insect Biochem. Mol. Biol.25, 153-176.

Baverstock, J., H. E. Roy, S. J. Clark, P. G. Alderson, J. K. Pell, 2006. Effect of fungal infection on the reproductive potential of aphids and their progeny. Journal of Invertebrate Pathology 91, 136-139

Carrillo, E., D. Rubiales, M. A. Castillejo, 2013. Proteomic Analysis of Pea (Pisum sativum L.) Response During Compatible and Incompatible Interactions with the Pea Aphid (Acyrthosiphon pisum H.). Plant Mol Biol Rep, doi:10.1007/s11105-0130677-x

Clement, S. L., K. E. McPhee, L. R. Elberson, M. A. Evans, 2009. Pea weevil, Bruchus pisorum L. (Coleoptera: Bruchidae), resistance in Pisum sativum $\mathrm{x}$ Pisum fulvum interspecific crosses. Plant Breeding, DOI: $10.1111 / \mathrm{j} .1439-$ 0523.2008.01603.x

Duncan, D., 1955. Multiple range and multiple F-test. Biometrics 11: 1-42.

Fan, Y., W. Fang, S. Guo, X. Pei, Y. Zhang, Y. Xiao, D. Li, K. Jin, M.J. Bidochka, Y. $P e i, 2007$. Increased insect virulence in Beauveria bassiana strains over expressing an engineered chitinase. Appl. Environ. Microbiol. 73:295-302.

Fernández-Grandon, G. M., S. J. Harte, J.
Ewany, D. Bray, P. C. Stevenson, 2020. Additive Effect of Botanical Insecticide and Entomopathogenic Fungi on Pest Mortality and the Behavioral Response of Its Natural Enemy. Plants, 9, 173; doi:10.3390/plants 9020173

French, R. J., 2004. Pea Agronomy. In: Wrigley,C., Corke, H. and Walker, C. (Eds.) „Encyclopedia of Grain Science'.pp. 427-437

Henderson, C. F., Tilton, E. W., 1955. Tests with acaricides against the brow wheat mite. J. Econ. Entomol., 48: 157-161.

Hernandez-Fernandez, J. A., 2016. Bacillus thuringiensis: a Natural Tool in Insect Pest Control. The Handbook of Microbial Bioresourses, 121-139.

Maiteki, G. A., R. J. Lamb, 1985. Growth Stages of Field Peas Sensitive to Damage by the Pea Aphid, Acyrthosiphon pisum (Homoptera: Aphididae). Journal of Economic Entomology, Volume 78, 1442-1448.

Megersa, A., 2016. Botanicals extracts for control of pea aphid (Acyrthosiphon pisum; Harris). Journal of Entomology and Zoology Studies, 4(1): 623-627.

Oguh, C. E., C. O. Okpaka, C. S. Ubani, U. Okekeaji, P. S. Joseph, E. U. Amadi, 2019. Natural Pesticides (Biopesticides) and Uses in Pest Management- A Critical Review. Asian Journal of Biotechnology and Genetic Engineering, 2(3): 1-18.

Sahito, H. A., M. B.r Arain, B. Mal, M. S. Channa, K. H. Dhiloo, 2013. Efficacy of Different Insecticides against Thrips on Peas, Pisum Sativum (L.) in Vivo Condition. Journal of Agriculture and Sustainability, 3(1), 56-77.

Shannag, H. S., J. L. Capinera, N. M. Freihat, 2014. Efficacy of different neem-based biopesticides against green peach aphid, Myzus persicae (Hemiptera: Aphididae). Int. J. Agric. Pol. Res., Vol.2 (2), 61-68. 
75 years of Agricultural University - Plovdiv JUBILEE SCIENTIFIC INTERNATIONAL CONFERENCE Plovdiv 26-28 November 2020
PERSPECTIVES ON AGRICULTURAL SCIENCE AND INNOVATIONS FOR SUSTAINABLE FOOD SYSTEMS

Sharma, H. C., C. P. Srivastava, C. Durairaj, C. L. L. Gowda, 2010. Pest management in grain legumes and climate change. In: Yadav, S.S.et al. (Eds.) Climate change and management of cool season grain legume crops, 115-139.

Wright, D. W., Q. A. Geering, 2009. The Biology and Control of the Pea Moth, Laspeyresia nigricana, Steph. https://doi.org/10.1017/S000748530002 $\underline{4299}$

Wrzodak, R. ,D. Rybczyński, 2010. Pea moth (Laspeyresia nigricana Steph.) control in integrated and ecological crops of pea. Progress in Plant Protection, Vol. 50, No.1, 467-470.

Xiao, Y., K. Wu, 2019. Recentprogress on the interaction between insects and Bacillus thuringiensis crops. Phil. Trans. R. Soc. B374:20180316.http://dx.doi.org/10.10 98/rstb.2018.0316

Yadav, S. K., S. Patel, 2015. Insect-pest complex on Pisum sativum $\mathrm{L}$. and their natural enemies at Pantnagar. Journal of Plant Development Sciences Vol. 7 (11): 839841. 